\title{
Assessment of Hepatic Mineral Composition in Sheep, Cattle, Chicken, and Fish in Erbil City, Kurdistan Region-Iraq
}

\author{
Abdulqader A. Hussein \\ Animal resources \\ Agricultural engineering sciences \\ University of Salahaddin-Erbil \\ Erbil, Iraq \\ abdulqader.hussein@su.edu.krd
}

Iman S. Ali

Fish Resources and Aquatic Animals

Agricultural engineering sciences

University of Salahaddin-Erbil

Erbil, Iraq

iman.ali@su.edu.krd

\author{
Samad S. Omer \\ Fish Resources and Aquatic Animals \\ Agricultural engineering sciences \\ University of Salahaddin-Erbil \\ Erbil, Iraq \\ samad.omar@su.edu.krd \\ Bnar F. Suleiman \\ Animal resources \\ Agricultural engineering sciences \\ University of Salahaddin-Erbil \\ Erbil, Iraq \\ bnar.sulaiman@su.edu.krd
}

Article Info

Volume 6-Issue 1- June 2021

DOI:

10.24017/science.2021.1.6

Article history:

Received: 20/02/2021

Accepted: 27/04/2021

\section{Keywords:}

Liver, minerals, ovine, bovine, checkin, fish

\begin{abstract}
Liver mineral concentrations of 232 samples from slaughtered animals, including lamb, yearling, sheep, and cattle, checkin, and fish were detrmined, using $X$-ray fluorescence spectrometer, to provide data regarding to the liver mineral concentrations ( $\mathrm{mg} / \mathrm{kg}$ dry weight). The mean liver $\mathrm{Zn}$ and Co liver conentrations of lambs (286, 1.9), yearling $(233,1.7)$, sheep $(254,1.8)$, and cattle $(276,1.8)$ in majority samples were adequate, while liver $\mathrm{Pb}$ concentrations of mentioned animals (45.3, 48.1, 46.4, $39.6) \mathrm{mg} / \mathrm{kg}$ respectively were high and exceeded toxic levels. In checkin, the mean liver $\mathrm{Cu}, \mathrm{Zn}$, and Co were also adequate, with the mean values of (26.4), (298.8), and (1.8) $\mathrm{mg} / \mathrm{kg}$ respectively. Though, the mean liver Fe concentration $(2257.0 \mathrm{mg} / \mathrm{kg})$ was high, and liver $\mathrm{Pb}$ concentration $(6.2 \mathrm{mg} / \mathrm{kg})$ was reached toxic level. In fish, for majority liver samples, the mean concentration of $\mathrm{Cu}$ (191.8), Fe (6800.0), Zn (202.8), Co (3.3), Pb (8.6), and Ni (6.3) were high and toxic. In conclusion, liver $\mathrm{Pb}$ (and $\mathrm{Ni}$ only in fish) concentration in all studied animals for the majority of examined sample were higher than normal and toxic. Wherese, other studied minerals in majority of liver samples were adequate. Therefore, it can be concluded that human and animal health at a potential risk due to high
\end{abstract}




\section{INTRODUCTION}

Minerals are exist in human and animal environment. There are minerals such as Iron, copper, zinc, manganese, cobalt, chromium, and selenium which are considered as essential elements in human and animal health. Wherese, minerals such as lead, nickel, arsenic, cadmium and mercury are considered as a toxic at certain levels ([1]; [2]). These minerals which are important and have their importance through involvement in formation of many enzymes and proteins contributed in key metabolic pathways. Thus, inappropriate supply of these minerals could retard the activity of enzymes, leading to metabolic disorders causing disease, reduce performance and economic loses. However, minerals when given to animals at higher levels than their requirements, exceeding the tolerance limit of the organism, can also lead to the alteration in cellular events, including lipid metabolism, gene expression, and distribution in hepatocytes, kidney damage, disruption in the nerve system, ae well as growth and reproduction retardation [3]; [4]. Consequently, exposure of animals to either high levels of minerals, or fed them levels lower than dietary requiremnt, can adversely affect animal production and health [4]. Moreover, dietary minerals that are offered at higher level than their requirements, however, by adapting to absorption and excretion, animals can limit the undesired accumulation of these minerals in tissues, or increasing in the mineral content of manure [5] : [6]. This may also elevate the amount of minerals in the soil and consume them through plants, which in long term, may consequence on animal when they consume plants in pastures.

Human consumption of meat and meat products derived from animal that accumulated high levels of minerals could adversely affect human health. In the food chain, due to its poisonous nature, bioaccumulation and bio-magnification, the existence of heavy metals may cause a serious threat. Additionally, the risk of exposure to heavy metals in meat and meat products is a threat for both human health as well as food safety because of their toxic nature. It could be noted, however, that the chemical forms of metals can be alter, but they can neither be degraded nor destroyed. Hence, International organisation such as the Food and Agricultural Organization (FAO), World Health Organization (WHO), US Environmental Protection Agency (USEPA) have been set the maximum permisible limit concentrations of heavy metals in foodstuffs. Recently, it has been reported that the level of heavy metals including $\mathrm{Pb}$, Ar, and $\mathrm{Ni}$ from imported meat of both lambs and beef in Erbil city were found higher than permitted levels set by international organization, which is considered as a risk to consumers health [7]. In Kurdistan region, ruminant animals mostly are not kept or housed in controlled farms that has fence and belonged pastures, while animals are free grazing along runways and other sites that might have been contaminated with toxic substances, or drink water from ditches, streams, rivers and other possible contaminated water sources. These animals are more liable to exposure to high levels of contaminants in the environment. These minerals are accumulated in the organs and other tissues such as liver and intestines which are sold in the market for consumption. Meat from sheep, cattle, poultry and fish can form an essential part of the human diet and contribute to consumers' overall exposure to toxic dietary elements. Liver is recognised as a most important organ, involving in the metabolic processes and storage of minerals. It is regarded to be representative as a most eloquent signs of any disturbance in the body. In addition, liver is the subject of different types of infectious, toxic, metabolic, nutritional, traumatic attacks or diseases [8]. In addition, liver contanis metal-binding proteins, by which heavy metals can accumulate at high concentrations. Hence, special consideration should be given to determine the concentration of minerals in liver. 
In view of the fact that there are very poor documented data on tissue minerals content of domestic animals in Erbil city- Kurdistan. The elements selected for this study are either known to be physiologically important in farm animals (Cu, Fe, Zn, and Co) ([9]; [4]) or to be of interest to food safety organisations ( $\mathrm{Pb}$ and $\mathrm{Ni}$ ) [10]. Therefore, this study aimed to investigate hepatic minerals concentrations in sheep, cattle, chicken, and fish in Erbil city where animals were raised or imported from other countries.

\section{METHODS AND MATERIALS}

\subsection{Sample collection}

A total of 281 ovine and bovine (local and imported such as Indian and Brazilian) livers samples were used in this study. The animals were not selected by sex, age, or breed, though on the acknowledged assumption that the lambs were weaned lambs, yearling aged no more than one year, and sheep over 2 years of age. Ovine and bovine liver samples were collected from slaughtered animals in Erbil city central slaughter house, chicken (broiler) liver samples were obtained from different slaughterhouses. Moreover, fish liver samples were collected from fishes in 5 different ponds. The collected species was Common Carp (Cyprinus Carpio). All liver samples were from animals belong to the territories of Erbil city in North of Iraq. Liver samples were collected through different time of the years 2018 and 2019. The number of animals per species were as followings; lamb (47), yearlings (34), sheep (32), cattle (50), chicken (20), and fish (49).

\subsection{Sample preparation}

Approximately 50g of liver tissue for each of ovine, bovine, and chicken were collected using stainless steel knives. Visible fat was removed, as well as connective tissue and major blood vessels. Moreover, whole fish liver samples were collected. Liver samples were packed in polyethylene bags, properly identified and preserved in a freezer at $-20^{\circ} \mathrm{C}$. Then, collected liver samples were oven dried at $60^{\circ} \mathrm{C}$ for 72 hours.

\subsection{Sample analysis}

The dried liver samples were analysed for copper $(\mathrm{Cu})$, iron $(\mathrm{Fe})$, Zinc $(\mathrm{Zn})$, cobalt $(\mathrm{Co})$, and lead $(\mathrm{Pb})$ concentrations using X-ray fluorescence spectrometer (Genius $9000 \mathrm{XRF}$, USA) according to the procedures of [11]. All the results were expressed in $\mathrm{mg} / \mathrm{kg}$ dry basis. Reported reference values, if given in wet weight (WW), were converted to dried weight DW for comparison purposes by multiplying reported WW values by 3.5 , which is the mid-point of the standard conversion rates used (range 3.0 to 4.0) ([12]; [4]). In addition, reference ranges reported in SI units $(\mu \mathrm{mol} / \mathrm{kg}$ ) were converted to $\mathrm{mg} / \mathrm{kg}$ by using the conversion factors provided by [12] and [4].

\subsection{Statistical analysis}

The experiment was a complete randomised design (CRD). One-way analysis of variance (ANOVA) was used to test for significant differences in hepatic minerals concentrations between species using Genstat version 19.1 (VSN Int. Ltd., Oxford, UK). Fisher's unprotected least significant difference test was applied between the means at a significant level of $\mathrm{p}<0.05$.

\section{RESULTS AND DISCUSSION}

To the best of our knowledge, this is the first comprehensive report about the selected minerals in Erbil City-Iraq from ovine, bovine, chicken, and fish liver; hence, only minimal comparisons can be made between our results and other data. 


\subsection{Ovine and bovine}

Generally, the mineral content evaluation in livestock is complicated. Besides, it is often impractical to determine minerals content in the diet or consumption of minerals in the pasture feeding situation or when offered a diet containing of various feed ingredients. Liver has been proposed as organ, using as an indicator for the status of several minerals concentration in ruminant, poultry, and fish ([13]; [14]; [15]). Other tissues do not represent consistently animal body mineral status. Therefore, the current study used the best method, which is liver tissue, to evaluate the mineral status in ovine, bovine, chicken, and fish [16]. The mean ( \pm standard deviation), median, and minimum, and maximum of liver essential trace minerals including $\mathrm{Cu}$, $\mathrm{Fe}, \mathrm{Zn}$, and $\mathrm{Co}$ and non-essential minerals such as $\mathrm{Pb}$ were measured in ovine, bovine, chicken, and fish. The obtained data are discussed in the framework of suggested values for classifying minerals status of these animals and they are also compared with minerals concentrations reported in the literature. To our knowledge, this is the first attempt to evaluate mineral content in slaughtered ovine, bovine, chicken, and fish in Erbil city. Copper. Iron, Zinc, and Cobalt is essential to all animals and functions as a cofactor in many enzyme systems. Although, deficiency or toxicity of these minerals in livestock could cause improvement in health and production [4]. Liver $\mathrm{Zn}, \mathrm{Co}$ and $\mathrm{Pb}$ concentrations, in the present study, of ovine and bovine were presented in Table 1 . These values were cpmpared with the diagnostic range for liver $\mathrm{Zn}$, $\mathrm{Co}$, and $\mathrm{Pb}$ concentrations in ovine and bovine (Table 2).

The majority of liver $\mathrm{Zn}$ concentration of analysed samples were adequate. In addition, there was no significant difference $(\mathrm{P}>0.05)$ in hepatic $\mathrm{Zn}$ concentrations between lambs, yearling, sheep, and cattle, with the mean value of 286, 233, 254, and $272 \mathrm{mg} / \mathrm{kg}$ respectively (Fig1). These mean values with median values of liver $\mathrm{Zn}$ concentration were adequate and slightly higher than normal range. Zn deficiency was not evidenced for examined animals. The minimum liver $\mathrm{Zn}$ concentration were ranging from 97 to $108 \mathrm{mg} / \mathrm{kg}$, which is adequate. Though, the maximum liver $\mathrm{Zn}$ concentration in examined animals reached high and a toxic level. The toxic level was just found in two cattle liver samples (>1400 mg Zn/kg). While, the high liver Zn concentration (for ovine 350-1400, and bovine 300-600 mg/kg) (Table 3) were observed in 12, 6, and 5, and 6 liver samples of lambs, yearling, sheep, and cattle respectively. Similarly, [17] reported high liver Zn concentration in sheep (4937 mg/kg DW) and cow (6489 $\mathrm{mg} / \mathrm{kg} \mathrm{DW}$ ). Both $\mathrm{Zn}$ and $\mathrm{Cu}$ are reported as antagonistic of each other. The high levels of either element will reduce absorption and metabolism of the other. They competitively bind to metallothionein. Increased dietary $\mathrm{Zn}$ results in decreased liver $\mathrm{Cu}$ concentration. Intakes of $\mathrm{Zn}$ impacts on $\mathrm{Cu}$ utilisation [18]. An increase of dietary $\mathrm{Zn}$ in lambs diet from $45 \mathrm{mg} / \mathrm{kg} \mathrm{DW}$ to 225 and $479 \mathrm{mg} / \mathrm{kg}$ DW reduced concentrations of $\mathrm{Cu}$ liver from 1625 to 1310 and $1158 \mathrm{mg} / \mathrm{kg}$ DW respectively [19]. The mechanism underlying the metabolic $\mathrm{Cu}-\mathrm{Zn}$ interaction has been proposed to potentially involve Metallothionein (MT) as Zn is suggested to induce MT [20]. Where $\mathrm{Zn}$ displaced $\mathrm{Cu}$ from sulfydryl binding site and then $\mathrm{Cu}$ bound to MT is excreted into intestinal lumen [21].

The mean, median, maximum, and minimum liver Co concentration of all examined animal were ranging from 1 to $3 \mathrm{mg} / \mathrm{kg}$ and these values are within normal range stated [1] and [4]. They proposed deficient, normal, and toxic concentration of liver Co concentration for both ovine and bovine were $0.04-0.06,0.08-0.12$, and $20-67 \mathrm{mg} / \mathrm{kg}$ respectively. The weaned lambs had higher $(\mathrm{P}<0.05)$ liver Co concentration compared with other studied animals (Fig. 1). Liver Co concentration of ovine and bovine in the current study were much lower compared to liver Co concentration in sheep $(22.4 \mathrm{mg} / \mathrm{kg} \mathrm{DW})$ and cow $(34.5 \mathrm{mg} / \mathrm{kg} \mathrm{DW})$ in Sulaymania city [17]. These difference in liver Co content could be due to the difference in dietary Co intake. The essentiality of Co for mammals is linked to vitamin B12 and there is no specific requirement for Co by mammalian tissues, though this mineral is required for the synthesis vitamin B12 via rumen microorganisms [22], which is a catalyst in the activity of methylmalonyl-CoA mutase and methionine synthase [23]. 
Table 1: Liver $\mathrm{Zn}, \mathrm{Co}$, and $\mathrm{Pb}$ concentrations of slaugtered ovine and bovine, with the diagnostic range

\begin{tabular}{|c|c|c|c|c|c|}
\hline Minerals & Animals & Mean \pm SD & Median & Minimum & Maximum \\
\hline \multirow{4}{*}{ Zn } & lamb & $286 \pm 145$ & 258 & 108 & 794 \\
\hline & yearling & $233 \pm 88$ & 207 & 136 & 564 \\
\hline & sheep & $254 \pm 117$ & 203 & 97 & 670 \\
\hline & local cattle & $272 \pm 259$ & 200 & 99 & 1664 \\
\hline \multirow{4}{*}{ Co } & lamb & $1.9 \pm 0.18$ & 1.8 & 1.6 & 2.3 \\
\hline & yearling & $1.7 \pm 0.10$ & 1.7 & 1.6 & 2.1 \\
\hline & sheep & $1.8 \pm 0.30$ & 1.8 & 1.4 & 3.0 \\
\hline & local cattle & $1.8 \pm 0.27$ & 1.7 & 1.0 & 3.0 \\
\hline \multirow{4}{*}{$\mathbf{P b}$} & lamb & $45.3 \pm 13.39$ & 45.2 & 21.6 & 81.7 \\
\hline & yearling & $48.1 \pm 12.60$ & 47.13 & 20.53 & 85.1 \\
\hline & sheep & $46.4 \pm 12.55$ & 49.9 & 16.1 & 72.5 \\
\hline & local cattle & $39.6 \pm 12.62$ & 41.4 & 20.6 & 71.7 \\
\hline \multicolumn{6}{|c|}{ Diagnostic range of liver $\mathrm{Zn}, \mathrm{Co}$, and $\mathrm{Pb}^{1}$} \\
\hline Animals & & & Zn & Co & $\mathbf{P b}$ \\
\hline \multirow{3}{*}{ Ovine } & Adequate & & 263 & 0.04 .06 & $0.11-2.8$ \\
\hline & High & & $350-1400$ & $0.08-0.12$ & 17.5 \\
\hline & Toxic & & $>1400$ & $20-69$ & $>35$ \\
\hline \multirow{3}{*}{ Bovine } & Adequate & & $25-200$ & 0.04 .06 & $0.35-3.5$ \\
\hline & High & & $300-600$ & $0.08-0.12$ & 7 \\
\hline & Toxic & & $>1000$ & $20-69$ & $>33$ \\
\hline
\end{tabular}

${ }^{1}[12]:[4]$

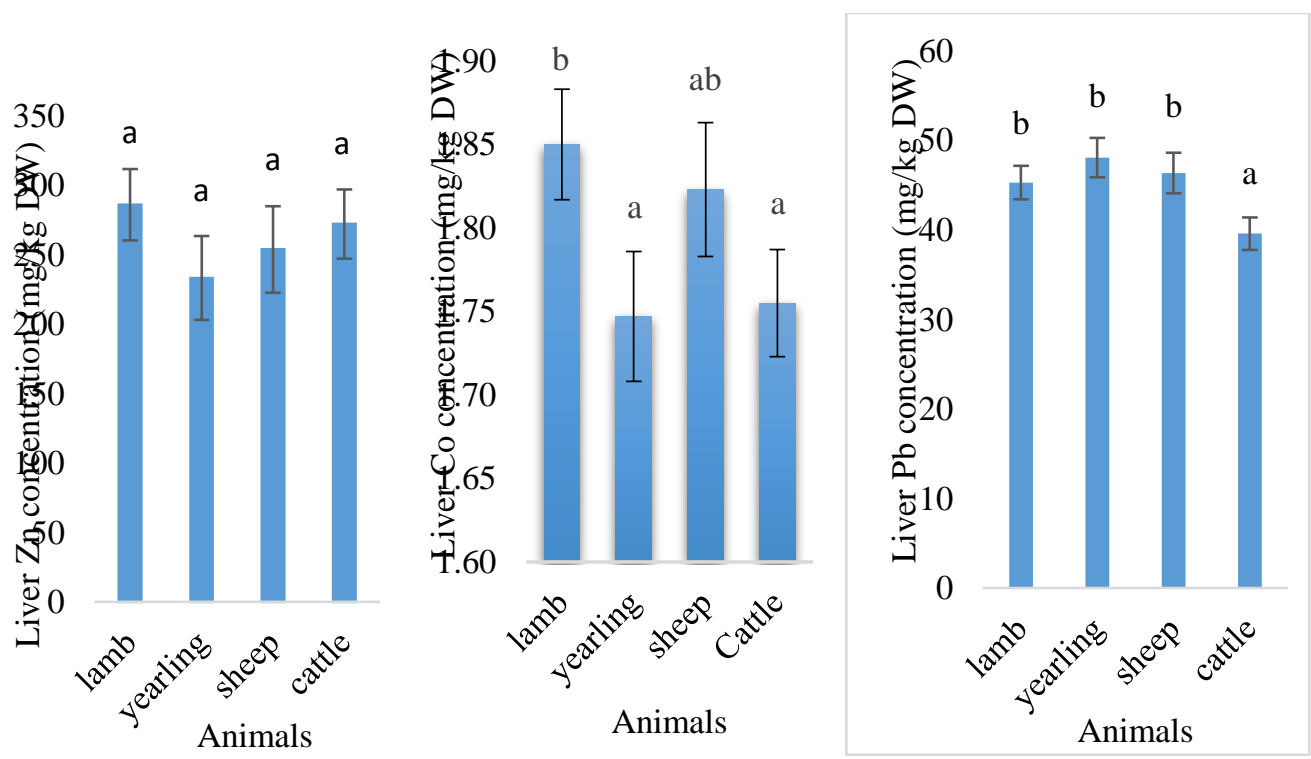

Figure 1: Liver Zinc ( $\mathrm{Zn})$, Cobalt $(\mathrm{Co})$, and Lead $(\mathrm{Pb})$ concentrations (mg/kg dry weight) of slaughtered local lambs, yearlings, sheep, and cattle in Erbil city abattoir. Error bars indicate SED. ${ }^{\mathrm{a}, \mathrm{b}}$ Means with different superscripts are significantly different $(\mathrm{P}<0.05)$ 
Liver $\mathrm{Pb}$ concentrations greater than 30 and $33 \mathrm{mg} / \mathrm{kg} \mathrm{DW}$ are taken as indication that the animal was at risk of toxicity to $\mathrm{Pb}$, while $7 \mathrm{mg} / \mathrm{kg} \mathrm{DW}$ was considered as an adequate ([12]; [4]). The mean and median liver $\mathrm{Pb}$ concentration of all studies animals were ranged between 38.5 and $49.9 \mathrm{mg} / \mathrm{kg}$. The maximum liver $\mathrm{Pb}$ concentration was $85.1 \mathrm{mg} / \mathrm{kg}$ in yearling animals, while the minimum level was $16.1 \mathrm{mg} / \mathrm{kg}$ in sheep. These values were considered more than adequate and high, exceeding the toxic level $33 \mathrm{mg} / \mathrm{kg}$ DW. Liver $\mathrm{Pb}$ content were lower $(\mathrm{P}<0.05)$ in cattle than lamb, yearling, and sheep. The results of current study were in accordance with the high liver $\mathrm{Pb}$ concentration in sheep $(38.9 \mathrm{mg} / \mathrm{kg} \mathrm{DW})$ and cow $(37.9 \mathrm{mg} / \mathrm{kg} \mathrm{DW})$ reported in Anbar city [24]. However, the higher liver $\mathrm{Pb}$. In cow (75 mg/kg DW) and the lower liver sheep $\mathrm{Pb}$ concentration $8.8 \mathrm{mg} / \mathrm{kg} \mathrm{DW}$ ) were reported in Sulaymania city [17]. It can be speculated that the cause of the toxic level of $\mathrm{Pb}$ in animals liver may be due to contaminations that transferred to animals via direct water, livestock feed, industrial effluent, and vehicle emission and from dirty slaughter places. As pastures on road borders polluted by high levels of $\mathrm{Pb}$, coming from fuel vehicle gases. As $\mathrm{Pb}$ tetraetileno was found in this fuel [25]. However, no data could be collected on diet, in this study. It is much more concise to test the dietary $\mathrm{Pb}$ content in several feed factories and farms in different site of Erbil city. This information can then be used to determine whether the high liver $\mathrm{Pb}$ content coming from diet or environment. Lead despite of having biological functions in animal body but is highly toxic to both animals and humans. This makes $\mathrm{Pb}$ regards as one of the most danger minerals to animal and human health, has worldwide distribution and is accumulated in environment by industrial pollution [2]; [26]. The effects of $\mathrm{Pb}$ on rumen microorganisms has not been fully understood. Although, it is assumed that $\mathrm{Pb}$ somehow can reduce or inhibit growth of rumen microorganisms, by which the rate of rumen microbial is reduced and forage digestion declines as well [27]. While, the adverse effect of $\mathrm{Pb}$ on human health could be due to the absorption of $\mathrm{Pb}$ in the small intestine, and then sequestered by the liver, transported in the erythrocytes, where it replaces Fe in several enzymes concerned with haemoglobin production. In addition, lead poisoned animal can be considered a risk to public health, since there is an accumulation of this mineral in animal tissues that used for human consumption it may result in human toxicities [28].

\subsection{Chicken}

The results for the five minerals, including $\mathrm{Cu}, \mathrm{Fe}, \mathrm{Zn}, \mathrm{Co}$, and $\mathrm{Pb}$, found in all liver chicken samples in Erbil city are summarised in Table 3. However, a scarcity of data and information are available regarding establishment of normal and toxic liver mineral concentrations in chicken. The diet is the main route of entry of most minerals into the animal body. In the environment, the source of minerals is coming from the combustion of waste disposal, fossil fuels, domestic sewage, and mining industries. In addition, forestry and farming are also contribute to the metal content in the environment via using of fertilizers and pesticide [29]; [26]. In the current study, the mean and median, with both maximum and minimum liver $\mathrm{Cu}$ and $\mathrm{Co}$ concentration of chicken were an adequate. Liver $\mathrm{Cu}$ concentration in poultry were ranging from 6.4 to $32 \mathrm{mg} / \mathrm{kg} \mathrm{DW}$, and chroning $\mathrm{Cu}$ poisoning was $127 \mathrm{mg} / \mathrm{kg} \mathrm{DW}$ [4]. In addition, liver Co concentration lower than $1 \mathrm{mg} / \mathrm{kg}$ DW was suggested as a deficient, and the level of 1.7-2.3 mg/kg DW were normal [30]. Though, the higher concentration of chicken liver $\mathrm{Cu}(158.3 \mathrm{mg} / \mathrm{kg} \mathrm{DW})$, but similar liver Co concentrations $(5.9 \mathrm{mg} / \mathrm{kg} \mathrm{DW})$ were reported in a study conducted in Sulaymaniah city-Iraq [17]. Although, liver Fe concentration was ranging between 2257 to $3100 \mathrm{mg} / \mathrm{kg}$, and these levels were considered as high but not reached toxic level of liver Fe concentration. The excess level of liver Fe concentration in poultry was set at $1000 \mathrm{mg} / \mathrm{kg}$ DW and the toxic level was $5992 \mathrm{mg} / \mathrm{kg}$ [4]. The similar reasons of high liver Fe concentration in ovine and bovine can be speculated. Although, the high level of Fe had no adverse effect on liver $\mathrm{Cu}$ concentration in the chickens from the current study. That is could be due to difference in $\mathrm{Cu}$ metabolism between ruminants and poultry [1]. 
Table 2: Slaughtered chicken liver minerals concentration ( $\mathrm{mg} / \mathrm{kg}$ dry weight).

\begin{tabular}{lccccc} 
& $\mathbf{C u}$ & $\mathbf{F e}$ & $\mathbf{Z n}$ & $\mathbf{C o}$ & $\mathbf{P b}$ \\
\hline Mean \pm SD & $26.4 \pm 16.97$ & $2257 \pm 347.80$ & $298.8 \pm 82.38$ & $1.8 \pm 0.08$ & $6.2 \pm 0.98$ \\
Median & 24.4 & 2122.0 & 280.3 & 1.8 & 5.9 \\
Minimum & 4.8 & 1958.0 & 204.6 & 1.6 & 4.7 \\
Maximum & 60.8 & 3100.0 & 501.2 & 1.9 & 7.7 \\
\hline
\end{tabular}

In poultry, liver $\mathrm{Zn}$ concentration $40-80 \mathrm{mg} / \mathrm{kg} \mathrm{DW}$ are set as an adequate, while $400 \mathrm{mg} / \mathrm{kg}$ DW as a high, and concentration greater than $400 \mathrm{mg} / \mathrm{kg}$ DW being suggestive of toxicosis [8]. In comparison with these levels, the mean and median in most liver $\mathrm{Zn}$ concentrations of slaughtered broilers in this study were within normal range. However, there were 3 samples of maximum liver $\mathrm{Zn}$ concentration $(501 \mathrm{mg} / \mathrm{kg}$ ) that exceeded the toxic threshold $400 \mathrm{mg} / \mathrm{kg} \mathrm{DW}$. Although, almost 3 times higher liver $\mathrm{Zn}$ concentration $(1324 \mathrm{mg} / \mathrm{kg} \mathrm{DW})$ in chicken has been reported by [17]. Generally, livestock show a high tolerance to high dietary $\mathrm{Zn}$ intake and the extent of tolerance depends on the presence of other minerals such as $\mathrm{Cu}$, and $\mathrm{Fe}$ in diet. In the current study, liver $\mathrm{Pb}$ concentration were between 4.7 (almost 5) and $7.7 \mathrm{mg} / \mathrm{kg} \mathrm{DW}$. Physiologic $\mathrm{Pb}$ concentrations in livers of poultry are $0.1-5 \mathrm{mg} / \mathrm{kg} \mathrm{DW}$, but the high level is set at $5-18 \mathrm{mg} / \mathrm{kg} \mathrm{DW}$, with concentrations of greater than $18 \mathrm{mg} / \mathrm{kg}$ DW being suggestive of toxicosis [4]. There were 19 chickens with liver $\mathrm{Pb}$ concentrations greater than $5 \mathrm{mg} / \mathrm{kg}$, and only one liver sample was $4.7 \mathrm{mg} / \mathrm{kg}$. However, none of liver samples contained or exceeded $(18 \mathrm{mg} / \mathrm{kg} \mathrm{DW})$ toxic level of $\mathrm{Pb}$.

\subsection{Fish}

The order of the fish liver mineral concentration was $\mathrm{Fe}>\mathrm{Zn}>\mathrm{Cu}>\mathrm{Pb}>\mathrm{Ni}>\mathrm{Co}$, with the mean values of $6800.0,202.8,191.8,8.6,4.9$, and $3.3 \mathrm{mg} / \mathrm{kg}$ respectively (Table 5). The mean and median of all analysed hepatic $\mathrm{Zn}, \mathrm{Cu}, \mathrm{Fe}, \mathrm{Pb}$, and $\mathrm{Ni}$ (except $\mathrm{Co}$ ) concentrations were higher than maximum permissible level(Table 4). The minimum liver $\mathrm{Cu}$ and $\mathrm{Zn}$ were below permissible limit, while minimum liver Fe concentration $(2434 \mathrm{mg} / \mathrm{kg})$ was higher than permissible limit. [31] observed that more iron concentrations resulted in decreased feeding rate and reduced growth, with behavioral changes. It is observed that $\mathrm{Zn}$ resulted in sublethal stress and elevated RBC count in fish [32]. it's also stimulated immune system via enhancing WBC count. Similarly, the high level of $\mathrm{Cu}$ could cause several disturbances such as the reduction of fish resistance to diseases through disrupting migration, altering swimming, impairing respiration, oxidative damage, disrupting osmoregulation structure and pathology of vital organs such as liver, gills, kidney, and other stem cells [33].

Table 3: Liver $\mathrm{Cu}, \mathrm{Fe}, \mathrm{Zn}, \mathrm{Co}, \mathrm{Pb}$, and $\mathrm{Ni}$ concentrations (mg/kg dry weight) in common carp fish from Erbil city ponds, and maximum permissible level of these minerals in fish ${ }^{1}$

\begin{tabular}{lcccccc}
\hline & $\mathbf{C u}$ & $\mathbf{F e}$ & $\mathbf{Z n}$ & $\mathbf{C o}$ & $\mathbf{P b}$ & $\mathbf{N i}$ \\
\hline Mean \pm SD & $191.8 \pm 121.10$ & $6800.0 \pm 6650.00$ & $202.8 \pm 177.30$ & $3.3 \pm 0.43$ & $8.6 \pm 1.63$ & $6.3 \pm 4.9$ \\
Median & 149.1 & 5730.0 & 122.7 & 3.0 & 8.9 & 4.9 \\
Minimum & 11.5 & 2434.0 & 10.17 & 2.1 & 4.2 & 0.3 \\
Maximum & 523.7 & 50201.0 & 772.8 & 3.8 & 12.0 & 20.1 \\
\hline Maximum permissible limit of trace minerals in fish according to some International Standards \\
\hline \multicolumn{7}{r}{} \\
\hline
\end{tabular}

\footnotetext{
${ }^{1}$ Adapted from [37]
} 
Moreover, reducing sperm and egg production [34]. The fish liver demonstrated as potential storage to accumulate various trace minerals. This potential to preferentially concentrate trace minerals in liver over muscle may attributed to elevated reaction rate with metallothioneins exist in liver. Therefore, the accumulation of these trace minerals in fish liver, in present study, is likely due to the role of liver in storage, metabolism and detoxification [35]. The mechanism by which explain the high hepatic $\mathrm{Cu}$ and $\mathrm{Zn}$ concentrations are mainly attributed to a natural binding protein such as metallothionein's (MT), which has a high affinity to bind with these minerals and acts as an essential metal store to attain enzymatic and other metabolic requirements. In the same way, Fe tends to store in liver tissues as aresult of the physiological role of the liver in blood cells and hemoglobin synthesis [36].

Lead is a persistent mineral which has been characterized as a priority hazardous substance [38]. In the present study, the minimum liver concentrations of $\mathrm{Pb}$ was $4.2 \mathrm{mg} / \mathrm{kg}$, which is greater than maximum acceptable concentration of lead in fish $(0.2-2 \mathrm{mg} / \mathrm{kg})$. [39] reported that $\mathrm{Pb}$ could result in weaken the immune system and increased susceptibility to infections. Nickel (Ni) is an essential element for living organisms, it is toxic when ingested in higher quantities. Nickel and nickel compounds are also well recognized as carcinogens [40]. The majority of liver fish samples were found higher than permissible limit $(0.5-1.0 \mathrm{mg} / \mathrm{kg})$. The mean and median liver fish Ni concentration were 6.3 and $4.9 \mathrm{mg} / \mathrm{kg}$ respectively, while the maximum concentration was $20.1 \mathrm{mg} / \mathrm{kg}$. These levels are much greater than permissible limit. According to the [41], the Ni exposure may lead to various health disorders such as nickel allergy, contact dermatitis, and organ system-toxicity. Liver Co concentrations were within acceptable range Mean value of Cobalt in fish livers was $3.3 \mathrm{mg} / \mathrm{kg}$, whereas minimum recorded concentration was $2.1 \mathrm{mg} / \mathrm{kg}$, while maximum recorded concentration was $3.8 \mathrm{mg} / \mathrm{kg}$. These values are lower than liver Co concentration $(5.2-16.7 \mathrm{mg} / \mathrm{kg}$ ) in common carp fish from farms in central Iraq [42].

Results of the current study were in acordance with the results of [43] whose founds that all study minerals in livers of $C$. carpio were in excess of permissible levels. Similar results have been reported that the very high fish liver concentrations of $\mathrm{Cu}, \mathrm{Zn}$, and $\mathrm{Pb}$, exceeding permissible levels [44]. It is stated that the high hepatic minerals concentration in fish can be used as an indication of water contamination by these minerals and monitor the extent to which water is polluted. This is due to the fact that the hepatic metal concentration in fish is proportional to those in aquatic environment [45]. Water contamination may, in other words, cause fish to be contaminated with heavy metals from anthropogenic domestic and industrial activities [46]. In addition, the very high hepatic contentration of $\mathrm{Cu}, \mathrm{Zn}$, and $\mathrm{Pb}$ have been attributed to contamination of water by industrial waste from untreated waste of factories along the Tigris River in Baghdad-Iraq [44]. The high liver fish concentration of all analysed minerals (except Co), with exceeding the maximum permissible limit in most of the studied fishes. These may affect fishes and human health safety [4]. A strong correlation has been reported between liver minerals concentration and fish meat minerals concentration [47]. Hence, it can be suggested that studied fishe are not suitable for human consumption.

\section{CONCLUSION}

The mean and median of analysed livers samples of ovine and bovine slaughtered in Erbil city for essatial minerals such as $\mathrm{Zn}$ and Co were within normal range. Although, mean and median liver $\mathrm{Pb}$ concentrations were exceded toxic levels. Checkin liver $\mathrm{Cu}, \mathrm{Zn}$, and Co contents were adequate based on their mean and median concentrations. While, Fe liver concentration was high. Chicken liver $\mathrm{Pb}$ concentrations were reached toxic level. The mean and median fish liver concentrations for essantial minerals such as $\mathrm{Cu}, \mathrm{Fe}, \mathrm{Zn}$, Co were higher than the maximum premissible concentration of these minerals in fish. In addition, liver fish concentrations for both $\mathrm{Pb}$ and $\mathrm{Ni}$ were also exceded the maximum premissible and resached toxic levels. This study 
revealed toxic levels of liver $\mathrm{Pb}$ and $\mathrm{Ni}$ (only in fish) in studied animals in Ebil city. Hence, it may be safe to say that high number of these animals are not fit for consumption due to their carcinogenic effects on animal and human health. In addition, it also suggests the environment and aquatic ecosystems pollution by these heavy metals.

\section{References}

[1] E,L, Underwood, N.F. Suttle, The mineral nutrition of livestock, 3rd edition, CABI Publishing, Wallingford, UK, 2004.

[2] National Research Council, Mineral tolerance of animals, National Academies Press, 2005.

[3] L.M. Gaetke, H.S. Chow-Johnson, C.K. Chow, "Copper: toxicological relevance and mechanisms," Archives of toxicology, 88(11), pp.1929-1938, 2014. DOI: 10.1007/s00204-014-1355-y

[4] N. F. Suttle, Mineral Nutrition of Livestock, 4th edition, CABI Publishing, wallinf ford, United Kingdom, 2010.

[5] F.A. Nicholson, B.J. Chambers, J.R. Williams, R.J. Unwin, "Heavy metal contents of livestock feeds and animal manures in England and Wales," Bioresource Technology, 70(1), pp.23-31, 1999. DOI:10.1016/S0960-8524(99)000176

[6] M.B. McBride, G. Spiers, "Trace element content of selected fertilizers and dairy manures as determined by ICPMS," Communications in Soil Science and Plant Analysis, 32(1-2), pp.139-156, 2001. DOI:10.1081/CSS-100102999

[7] N.Y. Yakupa, A.B. Sabowa, S.J. Saleh, G.R. Mohammed, "Assessment of heavy metal in imported red meat available in the markets of Erbil city," Journal of University of Babylon, 26(6), pp.177-183, 2018.

[8] B. Doneley, "Treating liver disease in the avian patient," In Seminars in avian and exotic pet medicine, 13 (1), pp. 8-15, 2004. DOI:10.1053/S1055-937X(03)00053-7.

[9] J.W. Spears, "Trace mineral bioavailability in ruminants," The Journal of nutrition, 133(5), pp.1506S-1509S, 2003. DOI:10.1093/jn/133.5.1506S

[10]D.J. MacLachlan, B.J. Blaney, L.G. Cook, E.Klim, R. Scholl , M. Sexton, J. Spragg, R.Watts, “A review of potential contaminants in Australian livestock feeds and proposed guidance levels for feed," Animal Production Science, 53(3), pp.181-208, 2013. DOI:10.1071/AN12048

[11]N.A. Cheleby, J.N. Bazzaz, N.Y. Yakub, A.A. Bazzaz, G.R. Hammad, "Heavy metal residues in frozen chicken meat consumed within Erbil province," Merit Res J, 3(11), pp.517-20. 2015.

[12]R. Puls, Mineral levels in animal health. Diagnostic data. Sherpa international, Clearbrook, British Columbia, Canada, 1994.

[13]J.P. Langlands, J.E. Bowles, G.E. Donald, A.J.Smith, "Deposition of copper, manganese, selenium and zinc in Merino sheep,” Australian Journal of Agricultural Research, 35(5), pp.701-707, 1984. DOI:10.1071/AR9840701

[14]O. Yayayürük, A.E. Yayayürük, "Determination of mercury, lead, caDWium, copper, iron and manganese in sheep, cow and chicken liver samples in Turkey," Gida/the Journal of Food, 42(5)., 2017. DOI:10.15237/gida.GD17018

[15]I. S. Ali, Water Quality Assessment for Greater Zab River and Bioaccumulation of Toxic Heavy Metals in Some Local Fish Species, Erbil, Kurdistan Region of Iraq, MSc. Thesis, Salahaddin University- Erbil, 2017.

[16]T.H. Herdt, W. Rumbeiha, W.E. Braselton, "The use of blood analyses to evaluate mineral status in livestock" Veterinary Clinics: Food Animal Practice, 16 (3), pp.423-444, 2000. DOI:10.1017/S0954422411000059

[17]P. Aljaff, B.O. Rasheed, D.M. Salh, "Assessment of heavy metals in livers of cattle and chicken by spectroscopic method,” IOSR Journal of Applied Physics, 6, pp. 23-26, 2014.

[18]L.R. McDowell, Minerals in animal and human nutrition, Academic press Inc. Harcourt Brace Jovanivich Publisher, San Diego, California, USA, 1992.

[19]W. Van der Schee, G.H. Van den Assem, R. Van der Berg, “ Breed differences in sheep with respect to the interaction between zinc and the accumulation of copper in the liver," Veterinary Quarterly, 5(4), pp.171-174, 1983.

[20]F. Tacnet, P. Ripoche, M. Roux, J.M. Neumann, “31 P-NMR study of pig intestinal brush-border membrane structure: effect of zinc and caDWium ions," European biophysics journal, 19(6), pp.317-322, 1991. https://doi.org/10.1007/BF00183321

[21]S.R. Gooneratne, W.T. Buckley, D.A. Christensen, "Review of copper deficiency and metabolism in ruminants," Canadian Journal of Animal Science, 69(4), pp.819-845,1989. DOI:10.4141/cjas89-096

[22]M.E. Tiffany, V. Fellner, J.W. Spears, "Influence of cobalt concentration on vitamin B12 production and fermentation of mixed ruminal microorganisms grown in continuous culture flow-through fermentors," Journal of animal science, 84(3), pp.635-640, 2006. DOI:10.2527/2006.843635x

[23]D.G. Kennedy, W.J. Blanchflower, J.M. Scott, D.G. Weir, A.M. Molloy, S. Kennedy, P.B. Young, "Cobalt-vitamin B-12 deficiency decreases methionine synthase activity and phospholipid methylation in sheep," The Journal of nutrition, 122(7), pp.1384-1390, 1992. DOI:10.1093/jn/122.7.1384

[24]H.M. Al-Nor, H.H. Nafee, "Some heavy metals residues in beef and sheep Liver in Anbar province," Al-Anbar Journal of Veterinary Sciences, 12(1), pp.37-49, 2019.

[25]W.K. Rumbeiha, W.E Braselton, D. Donch, "A retrospective study on the disappearance of blood lead in cattle with accidental lead toxicosis," Journal of veterinary diagnostic investigation, 13(5), pp.373-378, 2001. DOI:10.1177/104063870101300501

[26]L.S.L.D.S. Reis, P.E. Pardo, A.S. Camargos, E. Oba, E., "Mineral element and heavy metal poisoning in animals," Journal of medicine and medical Sciences, pp.560-579, 2010. 
[27]S.T. Strojan, C.J.C. Phillips, "The detection and avoidance of lead-contaminated herbage by dairy cows," Journal of dairy science, 85(11), pp.3045-3053, 2002. DOI:10.3168/jds.S0022-0302(02)74390-7

[28]D. Swarup, R.C. Patra, R. Naresh, P. Kumar, P. Shekhar, "Blood lead levels in lactating cows reared around polluted localities; transfer of lead into milk," Science of the Total Environment, 347(1-3), pp.106-110, 2005. DOI:10.1016/j.scitotenv.2004.12.055

[29]L. Friberg, G.F. Nordberg, V.B. Vouk, Handbook on the Toxicology of Metals, Elsevier/North-Holland Biomedical Press, 1979

[30]M. Gabrashanska, S. Tepavitcharova, M. Galvez-Morros, M. Mitov, "Investigation of the effect of cobalt compounds on uninfected and infected with Ascaridia galli chicks," Experimental Pathology and Parasitology, 4(7), pp.26-32, 2001

[31]M. Debnath, R.K. Saha, D. Kamilya, D. Saikia, H. Saha, "Effects of water borne iron on spawn of Indian major carps (Catla catla (Ham.), Labeo rohita (Ham.) and Cirrhinus mrigala (Ham.))," Bulletin of environmental contamination and toxicology, 89(6), pp.1170-1174, 2012. DOI:10.1007/s00128-012-0844-z.

[32]P.P. Buthelezi, V. Wepener, D.P. Cyrus, "The sublethal effects of zinc at different water temperatures on selected haematological variables in Oreochromis mossambicus," Southern African Journal of Aquatic Sciences, 25(1), pp.146151, 2000. DOI: $10.2989 / 160859100780177659$,

[33]C.A. Woody, S. O'Neal, Effects of Copper on Fish and Aquatic Resources, Fisheries Research and Consulting, Alaska, USA, pp. 26. W2013ECopperF062012.pdf (conservationgateway.org)

[34]F. Solomon, "Impacts of copper on aquatic ecosystems and human health," Environment and Communities, 25(8), pp.25-28, 2009

[35]F. Jabeen, A.S. Chaudhry, "Monitoring trace metals in different tissues of Cyprinus carpio from the Indus River in Pakistan," Environmental Monitoring and Assessment, 170(1-4), pp.645-656, 2010. DOI:10.1007/s10661-009-1263-4. [36]N. Sakulsak, "Metallothionein: an overview on its metal homeostatic regulation in mammals," International Journal of Morphology, 30(3), pp.1007-1012, 2012. DOI:10.4067/S0717-95022012000300039.

[37]J.O. Wilberforce, F. Nworie, R.O. Oti-Wilberforce, "Comparative assay of heavy metals in gills and muscles of common fishes in Afikpo, Ebonyi State, Nigeria," World Applied Sciences Journal, 34(2), pp.268-272, 2016. DOI: 10.5829/idosi.wasj.2016.34.2.15657

[38]D.G. Sfakianakis, E. Renieri, M. Kentouri, A.M. Tsatsakis, "Effect of heavy metals on fish larvae deformities: a review," Environmental research, 137, pp.246-255, 2015. DOI:10.1016/j.envres.2014.12.014.

[39]S.L. Shah, A. Altindağ, "Alterations in the immunological parameters of Tench (Tinca tinca L. 1758) after acute and chronic exposure to lethal and sublethal treatments with mercury, caDWium and lead," Turkish Journal of Veterinary and Animal Sciences, 29(5), pp.1163-1168, 2005.

[40]P.R. Shakya, "Nickel Adsorption by Wild type and Nickel Resistant Isolate of Chlorella sp.," Pakistan Journal of Analytical \& Environmental Chemistry, 8(2), p.5, 2007.

[41]Institute of Medicine, Dietary reference intakes applications in dietary planning, Subcommittee on interpretation and uses of dietary reference intakes and the standing committee on the scientific evaluation of dietary reference intakes, Institute of Medicine of the National Academies, The National Academies Press, Washington DC, pp. 248, 2003. DOI: $10.17226 / 10609$

[42]A.A. Hantoush, G.A. Al-Najare, A.H. Amteghy, H.T. Al-Saad, K. Abd Ali, "Seasonal variations of some trace elements concentrations in Silver Carp” Marsh Bulletin, 7(2), pp.126-136, 2012.

[43]A.M. Yousafzai, M. Siraj, A. Habib, D.P. Chivers, "Bioaccumulation of heavy metals in common carp: implications for human health,” Pakistan Journal of Zoology, 44(2), pp. 489-494, 2012.

[44]M. Mensoor, A. Said, "Determination of heavy metals in freshwater fishes of the Tigris River in Baghdad," Fishes, 3(2), p.23, 2018. DOI:10.3390/fishes3020023

[45]B. Jezierska, M. Witeska, Metal toxicity to fish, 1st edition, University of Podlasie, Siedlce, Polannd, pp. 318 2001

[46]J. Sun, Y. Ji, F. Cai, J. Li, Heavy Metal Removal Through Biosorptive Pathways. In: Sharma S., Sanghi R. (eds) Advances in Water Treatment and Pollution Prevention. Springer, Dordrecht, pp. 95-145, 2012. https://doi.org/10.1007/978-94-007-4204-8_5

[47]S. Faxneld, S. Danielsson, E. Nyberg, A. Bignert, "Conversion factors for metals between liver, muscle and wholebody in perch," Report 1, Swedish Museum of Natural History, 2015. https://www.divaportal.org/smash/get/diva2:811293/FULLTEXT01.pdf

[48]B.H. Marouf, "Association between serum heavy metals level and cancer incidence in darbandikhan and Kalar Area, Kurdistan Region, Iraq," Nigerian journal of clinical practice, 21(6), pp.766-771, 2018. DOI: 10.4103/njcp.njcp_384_16 